\title{
Influence of College Students' Mental Health Education on Ideological and Political Education
}

\author{
Li Zhao \\ Department of Political and History \\ Pingdingshan Institute of Education \\ Pingdingshan, China
}

\begin{abstract}
At present, in educational practice of Chinese universities mental health education and ideological and political education, there are still many deficiencies and gaps, making the development direction of attention and study of contemporary college students' psychological health education and ideological and political education work becomes necessary. Based on the analytical mental health education and ideological and political education content, similarities and differences between the dialectical relationships, this thesis is aim to describe the theoretical basis of the organic integration of the two educations, guidelines, and it will make detail solutions strategies, ways and methods.
\end{abstract}

Keywords- college students; mental health education; ideological and political education; organic integration

\section{THE CONNOTATION AND THE DIALECTICAL RELATIONSHIP BETWEEN MENTAL HEALTH EDUCATION AND IDEOLOGICAL AND POLITICAL EDUCATION}

Connotation of mental health education and ideological and political education, human psychology is innate, which can spontaneously generate in the human brain for cognitive feedback from external things. With the development of different individuals in contact with the environment, different individuals will form different psychological traits. Mental health education is in the process of natural development of the individual, to the interference of external ideology, and saves to add positive factors, abandon negative factors, a healthy, positive, good psychological quality, and eliminate the negative impact of mental illness, and promote healthy development of the individual. The main role of mental health education is to guide and control. Psychology Professor Song Guoqiang pointed out: "Good mental health education, include prevention of mental illness and mental quality of the training, and the two complement each other is nothing. The purpose of mental health education is to promote students to form a good psychological quality and promote the healthy development of the individual." [1] While thinking as a rational understanding, is a kind of perceptual processing and sublimation. Ideological and political education is based on philosophy, political science, sociology, ethics, etc., which belongs to the category of social science. Cultivating of contemporary college students' Ideological and political education is affected by the national interests of our national ideology, the ruling faction represent national interests and influence, with high political and national. Our ideological and political education of college students is consistent with our ideological and moral development of our society, which is making students, formed the values of world, life and values. Raising their political consciousness and moral qualities, emphasizing the concept is correct, moral and law-abiding are not only two important part of building a socialist spiritual civilization, but also is a part of promoting the foundation and guarantying for the development of China's socialist construction.

\section{The CRoss of MENTAL HeAlth EdUCATION AND IDEOLOGICAL AND POLITICAL EDUCATION}

Human psychology and the thinking is a unified whole, a very important aspect of the overall development of the human personality is the perfect all-round development and ideological progress. Integration of psychological education and ideological education is in line with the characteristics and laws of mental activity and thinking activity intrinsically linked, reflecting the scientific view of the political outlook of the concept of human unity. After the integration of education to more fully grasp the nature of man, a more coordinated manner is to promote the comprehensive development of the educated and the progressive improvement of personality. Integration of Psychological Education and Ideological Education optimization will enable both education and concerted efforts, the overall effectiveness of the two educational plays, which is to carry out two separate educations, is unmatched. Complete ideological and political education is necessary to create an interactive and social ethics as the main direction of the complete personality, but also a manifestation of national character and spirit of the times of educational content. Mental Health Education in the ideological and political education of students is more likely to be accepted. Function of ideological and political education and mental health education are intertwined and mutually reinforcing. 


\section{THE NECESSITY AND POSSIBILITY OF THREE IDEOLOGICAL AND POLITICAL EDUCATION AND MENTAL HEALTH EDUCATION COMBINING}

The necessity of the ideological and political education and mental health education has a long combination of ideological and political education, but it is often in a passive situation, which become a defensive consciously or unconsciously mission-style mode, with little different as Italian people, thereby constraining effect and impact of the implementation and the quality of education. The fundamental reason is somewhat utilitarian concept of education to ignore the meaning and value of human existence. The guiding ideology of social needs more consideration, ignoring meet human development needs; subjectivity educated easily overlooked; educational methods and means backward requirements of the times, even still stuck in the stage that "I say you listen to, I hit you pass". The empty talk more inspired than harsh criticism patient counseling. It not only cannot solve the problems in a timely manner, but also cause antagonism educated serious impact "affinity" between subject and object formation. In addition, some form of education monotone stifled many interesting educational content, but ideological and political education lost its appeal and appeal. So the ideological and political education of college students rebellious greatly damaged the ideological and political education work effect. The thinking and mental of contemporary college Students is very complex which often intertwined with psychological and ideological problems and psychological problems. Ideological and political education methods relied on traditional education are difficult to achieve a comprehensive understanding of the contemporary college students' mentality. How to guide students in the concepts, knowledge, ability, psychological quality meet the new requirements as soon as possible, is the ideological and political educators need to study and solve new problems. There are many other factors affect and restrict the ideology and quality formation and development of social, family and school. Education must train qualified personnel for the society. It is necessary for the educated-round development and training, which must include the psychological quality of training and training. Comprehensive ideological and political work should contain the psychological quality of training and improvement. Therefore, the combination of the two things can make ideological and political education under the guidance of psychological science, from the emotional to the personality, it is not only target at convincing to do a good job, but also enhance scientific ideological and political work. A combination of both can inspired by the ideological and political education workers, which change and expand their thinking in a greater use of psychological science research and work to improve the effectiveness of ideological and political education. Combined effect of ideological and political education and mental health education produced a single ideological and political education or mental health education cannot be compared. Therefore, ideological and political education and mental health education combined of students, it is not only the needs of solving psychological problems practical problems, but also the necessary of adapting to the realities of the times ideological and political education of college students.

\section{A. Approaches of college students' ideological and political education and mental health education have emphasized diversification}

Carrying out ideological and political education should actively explore and establish a social practice and professional learning combined with social services combined with a combination of work-study, the combination of employment and career management mechanism and with a combination of innovation and entrepreneurship. To build a socialist characteristics culture embody the characteristics of the times and school characteristics of campus culture, forming an excellent ethos, teaching style and the style of study. Mental Health education is a systematic project, which is aim at classroom teaching, extracurricular educational guidance as the main channel and the basic aspects of the formation curricular and extra-curricular, education and guidance, counseling and mental health funding closely integrated network and systems. Mental health education meet the needs of all students, through individual counseling, group counseling activities, and other forms of psychological and behavioral training. It is targeted to provide timely and effective mental health guidance and services to college students.

\section{B. The integration of education principles}

Mental health education should follow the principle of confidentiality and empathy (compassion, understanding heart) orientation, ideological and political education will have to adhere to the principles and values to guide public orientation. Actually, both cannot be fused. But in fact, during the course of these two educations, we have stressed the emotional education, practical and interactive. We also pay attention to the students' enthusiasm, initiative and creativity, attention to student's experience, understanding and reflection. This indicates that mental health education could not involve value-oriented issues, ideological and political education is not possible without empathy orientation, but in the specific context of education, varies depending on the specific circumstances favor it. Such as the campus psychodrama, values clarification discussions and other activities are sufficient to explain the psychological health education and ideological and political education, which have a tendency to follow a certain convergence in educational principles. Because in this activates, it can really achieve a good results of "heart educating the heart, to moral education moral, psychological education in Germany, in the heart of moral" through education and the educated of meticulous planning, mutual exchange, equal dialogue. Of course, in order to be effective at the level of integration of the principles of education, we must ensure that teachers have the appropriate knowledge and skills and a certain mental health education and ideological and political education in literacy. 
The specific objectives of mental education and ideological and political education are different. Specific goals of mental health education are improve students' psychological health, psychological quality optimization students, including college students living increase adaptability, enhancing psychological adjustment ability to correctly handle the confusion of learning communication love job development process to reduce the psychological conflict prevention and mitigation of psychological problems. The specific objectives of the ideological and political education are to improve the ideological and moral level of college students, optimize college students' ideological and moral qualities, including raising the ideological and political consciousness, establishing the correct ideals and beliefs, developing good moral character and enhancing the concept of law-abiding. Because mental health education and ideological and political education of the specific goals are different, which determines the function to both college students in the process of promoting the healthy growth of the role is different. Mental health education emphasize on the internal demand of students to promote personality development of students according to students, with significant individual functions. Ideological and political education is to emphasize individual behavior according to social requirements specification, with a clear social function. So in practice of education, mental health education is no substitute for the ideological and political education, ideological and political education is not a substitute for mental health education.

\section{Ideological and political education and mental health education penetrate each other, complement each other}

Ideological and political education and mental health education have focused on educational content that can complement each other. Ideological and political education is focused on the ideological level, while mental health education is focused on the psychological level, for example, mental health education is rarely set foot in some of the content of ideological and political education of Marxist theory and the Party's basic line of education, patriotism and collectivism education, and enhance mental health the problem of ideological and political education to develop psychological potential, resolve emotional disorders and other mental health education is also often difficult to take into account. But psychological and ideological levels are not completely separate; they belong to the same category of consciousness thing, which are involved in mind and spirit field. There are some issues of common interest between the two things, both on the specific content of the cross each other but complementary, with permeability. Both methods in education can learn from each other, especially in the ideological and political education of mental health education, which can learn from some of the systemic and operability of a strong theory and methods to enhance the students' active participation. Mental health education is the foundation of the ideological and political education. Thoughts are a high-level part of psychological phenomena.
It is namely the development of psychology from perceptual to rational thought process of understanding the process of human consciousness, which is actually the running of thoughts. The idea is the result of long-term accumulation of mental activity, evolving thinking by psychological factors and constraints. Therefore, ideological and political education is to master the psychological development and changes of people, which can solve the problem of people's thoughts and ideas to provide scientific methods and to improve the ability of solving practical problems, and enhance the ideological and political education with comprehensiveness, accuracy, profound and appeal.

\section{WAYS OF IDEOLOGICAL AND POLITICAL EDUCATION AND MENTAL HEALTH EDUCATION COMBINATION}

Mental health knowledge should be penetrated in the teaching of ideological and political theory courses. Ideological and Political Theory Teaching in college school should play the main channel in Moral work and the main role of the positions, which shoulder the important task of training students with good psychological and moral qualities. In fact, the process of teaching various courses and ideological and political theory courses should contain extremely rich psychological education factor, because the process of teaching is based on the historical and cultural heritage of the knowledge society, ethics, values, ideological content and dominated by these. In the process of Ideological and political theory course teaching in imparting knowledge should be aware of and concerned about the student's psychological needs, according to the psychological characteristics of students, adopting effective teaching methods to mobilize students' enthusiasm, making the knowledge of human history form, experience, and cultural transformation swift to students' spiritual wealth, internalizing into the students' ideas, values and good psychological quality.

\section{CONCLUSIONS}

It is the key to mental health education into ideological and political education to develop a teacher troop which does not only understand the law of ideological and political work, but also can master certain skills in mental health education. At first, the university should combine psychology teachers with the ideological and political education workers to make full use of the professional educational function and learn from each other, promoting two majors organic integration. Secondly, we should train teachers of working in the existing ideological and political education with the mental health education and encourage them to apply for counselors to enable them to master the basics of mental health education, skills, methods, flexible response to students' psychological problems which encountered in the work. Besides, we should enhance students' Mental Health Education. Student leaders were living in student groups, which can be kept informed of the student's psychological dynamics, acting as the "information workers" and they also plays an irreplaceable role in the ideological and political education work. At the 
same time, they are indispensable bridge and link in mental health education. Enhancing students' mental health education helps students grasp the psychological dynamics of their timely detection of abnormal psychology student problems and avoid serious incidents occurred at the same time, contributing to mental health literacy in the student population. At the same time, it can improve student's overall level of mental health and enhance students' ideological and political work effectiveness.

\section{References}

[1] Li Xiali. Ideological and Political Education and the integration of mental health education [J] education and occupation, 2007, 06: 7879.

[2] Xu Shuanghao. Why mental health education has become the ideological and political education research [J] Marxism Research, 2007, 03: 89-93 + 98 .

[3] Ding Yan. Ideological and Political Education and Mental Health Education fit $[\mathrm{J}]$ of Shandong Youth Administrative Cadres College, 2007, 03: 65-69.

[4] Luo Qin. Applied research [D] Mental Health Education in Ideological and Political Education. Nanjing Normal University,2013.
[5] Bo Lihua. All ideological and political education and mental health education to achieve the path of [J] ARTS AND SCIENCE, 2011, 04: 119-121.

[6] Zhao Lian. On organic ideological and political education and mental health education combined [J] EDUCATIONAL RESEARCH, 2010, 03: 65-67.

[7] Xu Xiaohui. ideological and political education and mental health education combined pathway [J] theorists, 2008, 02: 186-188.

[8] [8] Zhao Shibing. Mental Health Education and Political Education [J] ideological and political education research,2008, 01: 122-124 + 128.

[9] [9] Zhang Yunsheng. College Students' Mental Health Education and Political Education in combination [J] Henan University (Social Sciences), 2006,06: 158-161. 